Article

\title{
A Typological Characterization of Organic Livestock Farms in the Natural Park Sierra de Grazalema Based on Technical and Economic Variables
}

\author{
Cipriano Díaz-Gaona ${ }^{\circledR}$, Manuel Sánchez-Rodríguez, Thais Rucabado-Palomar and \\ Vicente Rodríguez-Estévez *(D) \\ Departamento de Producción Animal, Facultad de Veterinaria, Universidad de Córdoba, 14071 Córdoba, Spain; \\ pa2digac@uco.es (C.D.-G.); pa1sarom@uco.es (M.S.-R.); thaisruc@gmail.com (T.R.-P.) \\ * Correspondence: pa2roesv@uco.es; Tel.: +34-957218083
}

Received: 1 October 2019; Accepted: 25 October 2019; Published: 28 October 2019

check for updates

\begin{abstract}
This paper describes the typological characterization of the Natural Park Sierra de Grazalema (NPSG) livestock farms using its communal pastures ( $\mathrm{N}=23,100 \%$ of population) in order to study their sustainability from 160 technical, economic and social variables (from direct on-farm data collection). A principal components analysis (PCA) produced four principal components related to size, livestock species, main productions and intensification level, explaining $73.6 \%$ of the variance. The subsequent cluster analysis classified the farms into four groups: $\mathrm{C} 1$ (medium size farms without sheep), C2 (large size and very extensive farms), C3 (farms with multipurpose sheep) and C4 (farms with dairy goat and without cattle). Forty-eight-point-seven percent of the surface was registered as organic but none of the farms' commercialized products were organic. C2 and C3 (both having three ruminant species) are those farms that have more economic differences, the former generating the lowest profit, and the latter generating the highest; however, there is a risk to grasslands conservation from the current tendency that leads dairy farms to rapid intensification. Nevertheless, the very extensive farms are the most interesting for NPSG conservation and the administration should help to maintain the profitability of this sustainable traditional activity, which is necessary to conserve communal pastures.
\end{abstract}

Keywords: natural protected areas; communal pastures; farm typology; sustainability; extensive livestock; organic farming; agroforestry

\section{Introduction}

Numerous European landscapes and habitats—both natural and cultural-developed and persisted through the grazing of domestic ruminants. Many of these landscapes have a high level of biodiversity and are therefore very important for nature conservation [1]. However, the more extensively used sites are at risk of abandonment. The establishment and preservation of "pasture landscapes" with a mixed character of open grassland, shrubs and forests (agroforestry systems) have been recognized as a suitable strategy of management in several European countries, offering solutions for both nature conservation and traditional large-scale grazing systems [1]. In this context, the southern region of Spain (Andalusia) is the region with the largest protected area (1,784,992 ha), consisting of $27.3 \%$ of the protected area in the country [2]. Usually, its protected natural areas (PNA) are located in mountainous areas, which are agriculturally unproductive and traditionally exploited by extensive livestock and various complementary activities that have allowed for the preservation of many habitats [3]. Given the variety of ecosystems and the extension of the PNA in Andalusia, Rodríguez-Estévez et al. [4] and Díaz-Gaona et al. [3] suggest that these PNA are a sustainable model 
of management for grasslands and the use of natural resources for the rest of the Spanish territory. Of the 243 PNA in Andalusia, 24 consist of natural parks (NP), totaling 1,422,468 ha, 16.3\% of the region and $50.4 \%$ of its protected area [5]. Hence, this region, with a $32.3 \%$ proportion of protected terrestrial land, has one of the highest percentages in Europe, only surpassed by Bulgaria and Slovenia, which are both close to $35 \%$ [6].

In the inland NP of Spain, the proportion of public surfaces (39.3\%) is much lower than private ones $(60.7 \%)$, although there are significant differences between regions. Specifically, in Andalusia, this percentage is even lower since public areas occupy only $35.5 \%$ of the total area of inland NP [7] and are mainly above $1400 \mathrm{~m}$ altitude. As most of these PNA conserve their environmental values by their farmers and inhabitants' ancient rational use of resources and cultural heritage, it is necessary to maintain the sustainability of traditional extensive livestock farming. This is a general agreement for socio-ecological landscapes, with their future sustainability reliant on on-going agricultural management [8]. What is more, areas where farming practices are associated with high biodiversity value are often qualified as High Nature Value (HNV) farmland [9,10]. A large part of these HNV farmlands are also located in areas designated as 'less-favoured' from an economic perspective, with agricultural production restricted because of the characteristic factors of mountain areas (difficult climatic conditions, steep slopes and low soil productivity) [6]. As a consequence, these systems are being abandoned and may disappear due to a lack of profitability, or are being intensified; both negatively affecting PNA conservation [3]. Therefore, the biodiversity that depends on these low farm practices could be lost [6]. So, the balance of these agrosilvopastoral systems may be threatened by changes in the drivers of management [8].

In this context, current concern over environmental issues, climate change, food security, and the abandonment of rural areas (which results in a loss of traditional systems of production) causes the administration (environmental and agrarian authorities) to choose to link the future of PNA to sustainable livestock systems, as is the case with organic farming (OF) [3,11-14]. Hence, the continuity of traditional pastoral systems and agroforestry are key to the sustainability of these rural areas [3]. This, coupled with the recognition of the productive, environmental and social aspects of traditional grazing systems by agricultural policies and the marketing of quality products, is a boost for organic farming [3]. Besides, in Europe, the promotion of agroforestry has been shown as a solution for systems of high natural and cultural value [15], and farmers perceive their prominence in agroforestry.

Organic farming is a production system that, as a rule, respects the environment and has been developed in the EU since 1991 [16]. It has the support of the government and allows farmers to market their products with a certified label of quality. OF is an active sector, but improvements must be made for future consolidation of the sector.

Taking into account that traditional livestock production systems of the PNA are easily adapted to fulfill the requirements of OF regulation [12,17], OF is postulated as the most appropriate production system for the use and management of forage resources of the PNA, while these are conserved [3].

Moreover, pasture-based farming systems have a high diversity of characteristics and consequently a higher complexity and heterogeneity in relation to off-land farming systems [18]. This makes the typification of these kinds of farming systems very necessary and interesting, and this analysis can contribute to knowing these systems and increasing the global improvement and promotion of possibilities in these areas and their linked farms [18].

The characterization of a given production sector is based on the establishment of a typology of the farms that belong to that sector [19], and these typologies contribute to reducing heterogeneity by grouping farms according to similar characteristics. The analysis of structural, economic and social variables is useful to distinguish groups [20] and to discriminate while establishing typologies [21] as a tool to identify the structural features that define every livestock system. On top of that, from the typologies obtained it is possible to recommend improvement measures and specific policies for each of the groups identified [22]. 
Data analysis methods provide different tools or combination of tools to build typologies; for a review of farming system typology methodologies to study pasture-based farming systems see Madry et al. [18]. The most common statistical techniques to establish and characterize groups in livestock production systems are principal components analysis (PCA) and hierarchical clustering analysis with factorial analysis (i.e., [19,22-24]). Validation of typological results is often used to assess the differences between groups by means of ANOVA (i.e., $[23,25,26])$.

This study was conducted on the communal pastures of the Natural Park Sierra de Grazalema (NPSG) in Cádiz County (Southern Spain), which contains the Biosphere Reserve Sierra de Grazalema (the first one declared in Spain in 1977). The Use and Management Regulation of the NPSG indicates that $\mathrm{OF}$ will have preference in the use of public surfaces (grasslands and forests) [27]. What is more, grazing livestock provides services for wildfire prevention [28] and there is traditional shepherding knowledge of livestock management in the area that facilitates easy conversion to OF [29]. However, this NP is characterized by hilly terrains and adverse climatic conditions for agricultural production (seasonality of rainfall, extreme temperatures) and a high inter-year variability in grass production. Consequently, the profitability of its livestock systems should be studied and increased for their future consolidation; especially when considering the current climate change scenario.

There is a lack of knowledge about the current productive structures of the extensive and organic livestock farms in the studied area. However, due to the evolution of traditional and very extensive farms over the last decades, with the disappearance of many farms, abandonment of communal pastures, and gradual emergence of OF systems [29], it is necessary to characterize these farms in order to establish adequate policies for their support.

This study has a double objective: firstly to describe the typology of the farms that take advantage of the communal pastures of the NPSG in relation to their livestock management, and economic and social variables; and secondly to propose corresponding measures of improvement or support for these farms, especially in relation to organic farming livestock production.

\section{Materials and Methods}

\subsection{Study Area and Data Collection}

This study was conducted in the Natural Park Sierra de Grazalema (NPSG) (Cadiz, Southern Spain) on all the 23 farms that take advantage of its communal pastures, with an area of 13,919 ha $(26.1 \%$ of the NP) of which $69.9 \%$ are communal pastures. Seventy-four percent of these farms are registered as organic farms (OF) and produce in accordance with the Council of the European Union [12] regulations.

The NPSG belongs to the "Subbético" geological system and its composition is predominantly limestone. It shows areas of high slopes with an average altitude of about $900 \mathrm{~m}$, and a great diversity of habitats and vegetation, predominantly dehesa pastures and Mediterranean forest.

The climate in the region is Mediterranean, humid with mild temperature and seasonal rainfall, which ranges from 700 to $2300 \mathrm{~mm}$ per year. The annual temperature variation is moderate (about $20^{\circ} \mathrm{C}$ ); in winter, the average minimum temperatures are recorded between 4 and $11^{\circ} \mathrm{C}$ and the average maximum summer temperatures reaches values above $25^{\circ} \mathrm{C}[30,31]$.

The information was obtained through the collection of primary data from direct interviews with the farmers according to the methodology proposed by various authors [20,22,23,32,33]. The information gathered is highly reliable since it was collected by an experienced team. The interview questionnaire included 303 questions, relative to the following three aspects: sociology (27), exploitation system (224) and economy (52). Some of the questions to the farmers were about information that cannot be directly measured (i.e., data of purchase of a piece of machinery or of building of facilities). 


\subsection{Statistical Analysis}

The development of the typology was made from the methodology recently used by other authors (i.e., [20,22]), which consists of three stages: review and selection of variables, principal component analysis and cluster analysis.

In the first stage, 52 variables were selected, those with a coefficient of variation higher than $50 \%$. Then the correlation matrix was analyzed to eliminate uncorrelated variables and the one with the lowest coefficient of variation of each pair was analyzed with linear dependence [34]. Through this selection process the following 19 variables were obtained: farm surface area (ha), land in ownership $(\%)$, work unit (WU) per area (WU/100 ha), WU per livestock unit (LU) (WU/100 LU) (1 cow = $1 \mathrm{LU}$; 1 ewe $=0.15 \mathrm{LU} ; 1$ goat $=0.15 \mathrm{LU})$, stocking rate $(\mathrm{SR})(\mathrm{LU} / \mathrm{ha})$, cattle LU $(\%)$, sheep LU $(\%)$, goat LU $(\%)$, supplementary feed cost (€/ha and year), annual expenditure per tenancies and sharecropping ( $€ /$ ha and year), lamb sales ( $€ /$ ha and year), calf sales ( $€ /$ ha and year), kid sales ( $€ /$ ha and year), sheep milk sales ( $€ /$ ha and year), goat milk sales ( $€ /$ ha and year), subsidies for organic farming $(€ /$ ha and year), operating profit rate or rate of return (\%), profit (net entrepreneurial income) (€/ha and year) and relation sales/total income (\%).

In the second stage, PCA was used in order to reduce the number of variables and summarize the most variability [34]. The variables were standardized to avoid influence by the use of different scales [35]. Once the components were selected, the orthogonal quartimax rotation was applied to relate the selected variables more easily to the extracted factors. The Bartlett sphericity test and the Kaiser-Meyer-Olkin index were applied to verify sample adequacy (KMO >0.6) [36].

In the third stage, the farms were classified into groups using sequential cluster analysis. According to Martínez-González et al. [37] the hierarchical cluster was used as a clustering method, because it is the best suited to samples of less than 250 individuals. The final solution was found by the method of Ward and the Euclidean distance, properly classifying all farms. This procedure maximizes the homogeneity within groups and heterogeneity between groups [34].

For the development of statistical analysis SPSS ${ }^{\circledR} 11.5$ was used.

\section{Results}

\subsection{Characteristics of the Farms in the Communal Grasslands of the NPSG}

The farms with grasslands within the communal pastures of the NPSG cover an area of 13,919 ha (26.1\% of the NPSG), of which $69.9 \%$ belong to the communal pastures of the PNA and only $19.6 \%$ are owned by the farmers; the rest $(10.4 \%)$ is private grassland rented by these farmers. Moreover, $66 \%$ of the surface of these farms is registered as organic, although none of the surveyed farms has managed to commercialize products that are certified as organic on the organic market.

The variables used in the discriminant analysis to characterize these farming systems are shown in Table 1 . The average SR is $0.21 \mathrm{LU} / \mathrm{ha}$, although it has a high variability $(0.07-0.56 \mathrm{LU} / \mathrm{ha})$ due to different management systems (from extensive to semi-extensive), and it is higher than the average of $0.13 \mathrm{LU} / \mathrm{ha}(\mathrm{n}=67)$ found by Rodríguez-Estévez et al. [4] for all the OF in the NPSG. However, this average is lower than what other authors have found for extensive livestock in other areas with similar agro-ecosystems in the Spanish Southwest, mainly associated with dehesa (for a description of this agro-ecosystem see [38]). So, Escribano et al. [39] and Gaspar et al. [33] showed 0.37 and 0.38 LU/ha, respectively, for dehesa farms in Extremadura; Tierras [40], 0.38 LU/ha for Andalusian cattle farms; and Perea et al. [41], $0.36 \mathrm{LU} / \mathrm{ha}$ for Spanish organic cattle farms.

Animal production is very diversified in the NPSG, with several species and a high proportion of indigenous breeds: $94.9 \%$ of reproductive cows, $93.4 \%$ of reproductive goats and $64.6 \%$ of reproductive ewes; predominantly Retinta cows, Payoya goats and Grazalema Merino sheep, respectively. A good description of the traditional management of Payoya goats in this mountain area can be found in Gutierrez-Peña et al. [42]. These percentages are higher than those found by other authors for extensive 
farms in Southwestern Spain, from 59.1 to $83.5 \%$ [26,33,43,44]. Thirty-nine-point-one percent of farms have three species of ruminants, $56.4 \%$ have two and $4.3 \%$ have only one species.

Table 1. Descriptive statistics for technical, economic and social variables.

\begin{tabular}{|c|c|c|c|}
\hline & Mean & Standard Deviation & Coefficient of Variation \\
\hline Land in ownership (\%) & 19.62 & 23.91 & 121.88 \\
\hline Total rented surface $(\%)$ & 80.38 & 23.91 & 29.75 \\
\hline Total farm surface (ha) & 605.16 & 528.69 & 87.36 \\
\hline Surface registered as organic $(\%)$ & 48.66 & 37.94 & 77.98 \\
\hline Cattle stocking rate (LU/ha) & 0.08 & 0.08 & 99.17 \\
\hline Sheep stocking rate (LU/ha) & 0.05 & 0.05 & 107.58 \\
\hline Goat stocking rate (LU/ha) & 0.07 & 0.06 & 78.06 \\
\hline Total stocking rate (LU/ha) & 0.21 & 0.12 & 58.23 \\
\hline Cattle LU/Total LU (\%) & 37.89 & 24.68 & 65.14 \\
\hline Sheep LU/Total LU (\%) & 23.77 & 21.28 & 89.51 \\
\hline Goat LU/Total LU (\%) & 36.93 & 26.71 & 72.34 \\
\hline Ewe replacement rate (\%) & 10.16 & 8.64 & 85.04 \\
\hline Lambs sold per year & 150.55 & 275.43 & 182.95 \\
\hline Cow replacement rate $(\%)$ & 13.04 & 9.26 & 71.00 \\
\hline Calves sold per year & 22.94 & 26.05 & 113.54 \\
\hline Goat replacement rate $(\%)$ & 20.94 & 11.82 & 56.45 \\
\hline Kids sold per year & 191.54 & 198.32 & 103.54 \\
\hline Total work units per area (WU/100 ha and year) & 0.49 & 0.30 & 60.91 \\
\hline Fixed work units per area (WU/100 ha and year) & 0.04 & 0.13 & 360.07 \\
\hline Temporary work units per area (WU/100 ha and year) & 0.01 & 0.01 & 141.39 \\
\hline Family work units per area (WU/100 ha and year) & 0.44 & 0.26 & 59.49 \\
\hline Total work units per animal (WU/100 LU and year) & 2.40 & 1.12 & 46.66 \\
\hline Fixed capital per area $(€ / \mathrm{ha})$ & 938.17 & $1,143.48$ & 121.88 \\
\hline Buildings' fixed capital (€/ha) & 47.90 & 54.38 & 113.53 \\
\hline Machinery fixed capital (€/ha) & 16.80 & 18.54 & 110.39 \\
\hline Livestock fixed capital (€/ha) & 115.58 & 74.07 & 64.09 \\
\hline Supplementary feed $(\mathrm{Kg} / \mathrm{ha}$ and year) & 28.47 & 50.25 & 176.52 \\
\hline Veterinary costs ( $€$ /ha and year) & 1.25 & 0.98 & 78.54 \\
\hline Other goods and services per area $(€ / \mathrm{ha})$ & 13.37 & 9.53 & 71.32 \\
\hline Intermediate consumption $(€ /$ ha) & 43.08 & 53.20 & 123.48 \\
\hline Labor costs per area $(€ /$ ha and year) & 63.23 & 38.52 & 60.93 \\
\hline Fixed capital consumption (amortization) per area ( $€ /$ ha) & 2.64 & 2.60 & 98.37 \\
\hline Rents paid per area $(€ /$ ha and year $)$ & 12.62 & 9.42 & 74.62 \\
\hline Livestock sold per area (€/ha and year) & 58.31 & 64.08 & 109.89 \\
\hline Other products sold per area $(€ /$ ha and year) & 85.94 & 68.23 & 79.39 \\
\hline Fixed capital goods produced on own account ( $€$ /ha and year) & 20.15 & 14.64 & 72.64 \\
\hline $\begin{array}{c}\text { Total incomes from farming production (gross output) per } \\
\text { area (€/ha and year) }\end{array}$ & 164.40 & 119.27 & 72.55 \\
\hline $\begin{array}{l}\text { Subsidies to farming (different to organic farming support) per } \\
\text { area ( } € / \text { ha and year) }\end{array}$ & 30.39 & 20.30 & 66.80 \\
\hline Subsidies to organic farming per area (€/ha and year) & 19.61 & 30.02 & 153.08 \\
\hline Net value added at factor cost per area ( $€$ /ha and year) & 168.68 & 115.39 & 68.41 \\
\hline Net operating surplus per area (€/ha and year) & 105.45 & 90.74 & 86.05 \\
\hline Net entrepreneurial income per area $(€ /$ ha and year) & 92.83 & 88.17 & 94.98 \\
\hline Rate of return & 18.00 & 20.11 & 111.71 \\
\hline Breakeven point (LU/ha) & 0.09 & 0.05 & 51.14 \\
\hline Profit (€/ha and year) & 92.83 & 88.17 & 94.98 \\
\hline Total sales/total incomes & 73.33 & 17.72 & 24.17 \\
\hline Total subsidies/total incomes & 26.67 & 17.72 & 66.46 \\
\hline Incomes from lambs sold (€/ha and year) & 9.05 & 10.24 & 113.11 \\
\hline Incomes from sheep milk sold ( $€ /$ ha and year) & 14.19 & 34.40 & 242.43 \\
\hline Incomes from calves sold (€/ha and year) & 20.81 & 28.36 & 136.25 \\
\hline Incomes from kids sold (€/ha and year) & 16.71 & 15.04 & 90.02 \\
\hline Incomes from goat milk sold ( $€ /$ ha and year) & 71.75 & 69.20 & 96.45 \\
\hline
\end{tabular}

Regarding the farm surface area, the farms studied have a mean of 605 ha grazed by an average flock of $108 \mathrm{LU}$. Therefore, the mean herd of cattle is $60 \mathrm{LU} /$ farm (Table 2). This size is lower than that reported by Perea et al. [45] (98.8 LU) for organic farms in Andalusia; and is approximately half the size of the herds from other dehesa areas, for instance: 133.8 LU [46] and 124.9 LU [26]. 
Table 2. Descriptive statistics for livestock census and stocking rates.

\begin{tabular}{cccccccc}
\hline & N & Mean & \pm & $\begin{array}{c}\text { Standard } \\
\text { Error }\end{array}$ & $\begin{array}{c}\text { Standard } \\
\text { Deviation }\end{array}$ & Q1 & Q3 \\
\hline Cattle LU & 18 & 60.15 & \pm & 12.07 & 51.22 & 22.60 & 84.29 \\
Sheep LU & 16 & 39.80 & \pm & 10.95 & 43.80 & 11.52 & 39.86 \\
Goat LU & 20 & 36.23 & \pm & 6.95 & 31.09 & 21.00 & 41.03 \\
Swine LU & 4 & 11.87 & \pm & 6.52 & 13.05 & 1.05 & 25.17 \\
Total LU & 23 & 108.32 & \pm & 23.47 & 112.55 & 47.17 & 133.74 \\
Cattle SR * & 18 & 0.10 & \pm & 0.02 & 0.08 & 0.05 & 0.15 \\
Sheep SR * & 16 & 0.07 & \pm & 0.01 & 0.05 & 0.03 & 0.11 \\
Goat SR * & 20 & 0.09 & \pm & 0.01 & 0.05 & 0.04 & 0.13 \\
Ruminants SR * & 23 & 0.20 & \pm & 0.02 & 0.11 & 0.11 & 0.25 \\
Swine SR * & 4 & 0.04 & \pm & 0.02 & 0.04 & 0.00 & 0.08 \\
Total SR * & 23 & 0.21 & \pm & 0.03 & 0.12 & 0.11 & 0.25 \\
Cattle LU/Total LU (\%) ${ }^{* *}$ & 18 & 48.41 & \pm & 3.72 & 15.77 & 40.66 & 56.51 \\
Sheep LU/Total LU (\%) $*$ & 16 & 34.17 & \pm & 4.22 & 16.88 & 26.10 & 41.92 \\
Goat LU/Total LU (\%) ** & 20 & 42.46 & \pm & 5.38 & 24.06 & 21.10 & 58.51 \\
Swine LU/Total LU (\%) ${ }^{* *}$ & 4 & 8.15 & \pm & 3.85 & 7.69 & 1.59 & 15.92 \\
\hline
\end{tabular}

* SR: stocking rate (LU/ha). ${ }^{* *}$ These percentages correspond to those farms with the species.

The mean numbers of small ruminant flocks have 40 and $36 \mathrm{LU} /$ farm for sheep and goats, respectively (Table 2). This sheep flock size is greater than indicated by Ruiz et al. [47] for mixed small ruminant flocks of Sierra de Cádiz and Serranía de Ronda (6.8 LU/farm). However, these researchers found a similar herd size for the goats (30.9 LU/farm). The herds of goats described by Gaspar [46] for dehesa farms in Extremadura are similar (41.0 LU), although this species was only found in $8.7 \%$ of those farms, while it was found in $86.9 \%$ of the NPSG farms.

The goat SR is negatively correlated with the farm surface area $(r=-0.467, p<0.05)$ (Table 3); because this species, which in this area is generally exploited for the production of milk in semi-extensive systems, is more related to small and family farms [25]. This correlation does not exist in other species. These results differ from those reported by other authors for dehesa farms. Escribano et al. [39] indicate negative correlations between the total area and SR levels, being more evident for cattle $(r=-0.394$, $p<0.01$ ), which increases SR levels in smaller farms. Gaspar et al. [33] also found a negative correlation between the land surface and the total SR $(r=-0.30, p<0.05)$, indicating that the larger the surface, the less livestock there is. Escribano et al. [39] also highlighted the negative correlation between sheep and beef SR ( $r=-0.297, p<0.05)$, which shows that, unlike the case in NPSG in dehesa farms of Extremadura, simultaneous farming of both ruminants is not frequent and an increase in SR of one species of these conditions means a decrease in the other.

The workforce (annual work unit $=$ AWU) is employed in an average of 1.9 AWU/farm and year (1 AWU/42 LU); García et al. [48] found a similar result in farms located in the mountains of Jaen (1.8 AWU/farm and year), another province of the same region with mountain livestock systems. However, this is higher than that reported by Perea et al. [45] for Andalusian organic cattle farms and by Gaspar et al. [20] for extensive herds of goats in the region of the Villuercas-Ibores (Cáceres, Extremadura) (1.6 AWU/farm and year). Ninety-three-point-four percent of the workforce of the farms studied is familiar; similar to the $85 \%$ reported by [49] for Extremadura dairy goat farms, and higher than the 39\% found by Gaspar [46] for dehesa farms of Extremadura. This result is mainly attributed to the family nature of traditional milk production in Andalusia [50] and in the area [25]; especially considering that $96 \%$ of the farms studied produce goat or sheep milk.

Fixed costs (salaries, rents paid for leasing and amortization) are much higher (64.6\%) than variable costs (feed, veterinary services and other goods) (35.4\%), which is a major constraint on the improvements design for these systems. Labor is the largest cost $(52 \%)$. 
Table 3. Matrix of Pearson correlations for the census (livestock units: LU) and stocking rates (SR; LU/ha) and surface.

\begin{tabular}{cccccc}
\hline & Sheep LU & Goat LU & Swine LU & Total LU & Cattle SR \\
\hline Cattle LU & $0.723^{* *}$ & $0.894^{* *}$ & 0.948 & $0.930^{* *}$ & 0.411 \\
Sheep LU & & $0.920^{* *}$ & -0.828 & $0.919^{* *}$ & 0.202 \\
Goat LU & & & 0.943 & $0.914^{* *}$ & 0.276 \\
Swine LU & & & 0.839 & 0.934 \\
Total LU & & & & $0.429^{*}$ \\
\hline & Sheep SR & Goat SR & Swine SR & Total SR & Total Surface \\
\hline Cattle LU & 0.327 & 0.215 & 0.173 & 0.461 & $0.602^{* *}$ \\
Sheep LU & 0.487 & 0.174 & -0.192 & 0.328 & 0.355 \\
Goat LU & $0.548^{*}$ & 0.282 & -0.097 & $0.482^{*}$ & 0.437 \\
Swine LU & 0.327 & 0.21 & $0.980 *$ & 0.95 & -0.398 \\
Total LU & 0.386 & 0.021 & 0.119 & $0.476^{*}$ & $0.534^{* *}$ \\
Cattle SR & 0.108 & -0.112 & $0.766^{* *}$ & $0.779 * *$ & -0.039 \\
Sheep SR & & -0.1 & -0.03 & $0.448^{*}$ & -0.077 \\
Goat SR & & & 0.071 & 0.372 & $-0.467 *$ \\
Swine SR & & & & $0.696^{* *}$ & -0.163 \\
Total SR & & & & & -0.31 \\
\hline
\end{tabular}

${ }^{*} p<0.05,{ }^{* *} p<0.01$.

Cost indicators highlight their high positive correlation $(p<0.01)$ with cattle SR (Table 4$)$, except for rents paid for rented grasslands. In contrast, sheep SR has only a positive correlation with the rents paid for rented grasslands $(r=0.499, p<0.05)$. This indicates that farms whose main production comes from sheep have the largest percentage of rented land for grazing, which contributes to reducing costs, such as those caused by supplementary feed. As far as goats are concerned, it highlights the high correlation between the SR and salaries $(r=0.782, p<0.01)$, due to the greater needs of labor that milk production demands. It also highlights the correlation $(\mathrm{r}=0.484, p<0.05)$ between goat $\mathrm{SR}$ and consumption of other goods and services; with their greatest needs associated with milking.

Table 4. Matrix of Pearson correlations for stocking rates of different species (SR; LU/ha) and economic indicators.

\begin{tabular}{|c|c|c|c|c|c|}
\hline & & Cattle SR & Sheep SR & Goat SR & Total SR \\
\hline \multirow{4}{*}{$\begin{array}{l}\text { Cost } \\
\text { indicators }\end{array}$} & Veterinary costs $(€ /$ ha and year $)$ & $0.489 *$ & 0.276 & 0.385 & 0.382 \\
\hline & Intermediate consumption ( $€ /$ ha and year) & $0.880 * *$ & -0.144 & 0.227 & $0.719 * *$ \\
\hline & Labor costs per area $(€ /$ ha and year $)$ & $0.811^{* *}$ & 0.302 & $0.782 * *$ & $0.606^{* *}$ \\
\hline & Amortization (€/ha and year) & $0.640^{* *}$ & 0.01 & $0.560 *$ & 0.398 \\
\hline \multirow{4}{*}{$\begin{array}{l}\text { Income } \\
\text { indicators }\end{array}$} & Livestock sales (€/ha and year) & $0.952 * *$ & 0.101 & 0.275 & $0.915^{* *}$ \\
\hline & Milk sales (€/ha and year) & $0.575 *$ & $0.641 * *$ & $0.925^{* *}$ & $0.495 *$ \\
\hline & $\begin{array}{l}\text { Fixed capital goods produced on own account } \\
\qquad(€ / \text { ha and year })\end{array}$ & $0.934^{* *}$ & 0.398 & 0.332 & $0.902 * *$ \\
\hline & Subsidies to farming (€/ha and year) & $0.799 * *$ & $0.679 * *$ & $0.721 * *$ & $0.802^{* *}$ \\
\hline \multirow{4}{*}{$\begin{array}{l}\text { Other } \\
\text { economic } \\
\text { indicators }\end{array}$} & Net operating surplus (€/ha) & $0.564 *$ & $0.779 * *$ & $0.739 * *$ & $0.669 * *$ \\
\hline & $\begin{array}{l}\text { Net entrepreneurial income } \\
(\text { profit })(€ / \text { ha) }\end{array}$ & $0.579 *$ & $0.747^{* *}$ & $0.750 * *$ & $0.669 * *$ \\
\hline & Working capital (€/ha) & $0.898 * *$ & 0.03 & $0.504 *$ & $0.747 * *$ \\
\hline & Rate of return (\%) & -0.111 & 0.136 & 0.128 & -0.022 \\
\hline
\end{tabular}


The main income comes from sales of milk (40.1\%). Subsidy payments account for $23.3 \%$ of incomes, and more than a third of these $(9.1 \%)$ correspond to organic production. Incomes have a high positive correlation $(p<0.01)$ with total SR (Table 4$)$; except those from subsidies to organic farming, which do not depend on production [51].

The average rate of profitability of these farms is high $(15.7 \pm 3.5 \%)$, mainly due to their low fixed capital. The average benefit is $92.8 \pm 18.4 € /$ ha, significantly higher $(184.3 € /$ ha) on farms with more SR ( $>0.22 \mathrm{LU} / \mathrm{ha}$ ) and those receiving the subsidy derived from organic production policies $(140.9 € / \mathrm{ha})$.

\subsection{Principal Components Characterizing the Farms}

The KMO test of sampling adequacy showed a value of 0.6 while the Bartlett's sphericity test showed a satisfactory probability value $(p<0.001)$, indicating the suitability of the analysis. The first four factors that accounted for $73.6 \%$ of the original variability were selected (Table 5).

Table 5. Principal components (PC) selected, eigenvalues, explained and accumulated variances, and correlation coefficients of the variables with each PC.

\begin{tabular}{|c|c|c|c|}
\hline PC & $\begin{array}{c}\text { Eigenvalue \% Variance } \\
\text { Explained } \\
\text { (\% Variance Accumulated) }\end{array}$ & Variables & $\begin{array}{c}\text { Correlation with } \\
\text { the PC }\end{array}$ \\
\hline \multirow[t]{7}{*}{1} & 4.8 & Total work units per animal (WU/100 LU and year) & 0.9 \\
\hline & 25.1 & Goat LU/Total LU & 0.8 \\
\hline & $(25.1)$ & Incomes from goat milk sold per area (€/ha and year) & 0.8 \\
\hline & & Incomes from kids sold per area (€/ha and year) & 0.7 \\
\hline & & Work units per area (WU/100 ha and year) & 0.6 \\
\hline & & Farm surface (ha) & -0.8 \\
\hline & & Cattle LU/Total LU & -0.8 \\
\hline \multirow[t]{5}{*}{2} & 4.0 & Incomes from calves sold per area ( $€ /$ ha and year) & 0.9 \\
\hline & 21.3 & Stocking rate (LU/ha) & 0.9 \\
\hline & $(46.4)$ & Supplementary feed ( $€ /$ ha and year) & 0.9 \\
\hline & & Land in ownership (\%) & 0.7 \\
\hline & & Profit $(€ /$ ha and year $)$ & 0.5 \\
\hline \multirow[t]{4}{*}{3} & 3.0 & Sheep LU/Total LU & 0.9 \\
\hline & 16.0 & Lambs sold (€/ha and year) & 0.8 \\
\hline & $(62.4)$ & Sheep milk sold (€/ha and year) & 0.8 \\
\hline & & Rents paid $(€ /$ ha and year) & 0.5 \\
\hline \multirow[t]{3}{*}{4} & 2.1 & Subsidies to organic farming per area ( $€ /$ ha and year) & 0.9 \\
\hline & 11.2 & Rate of return per area $(€ /$ ha and year $)$ & 0.6 \\
\hline & (73.6) & Total sales/total incomes & -0.8 \\
\hline
\end{tabular}

The first principal component (PC) explains $25.1 \%$ of the variability and is associated with indicative variables of the farm dimension, use of labor, percentage of goat $\mathrm{LU}$ and goat production (kids and milk) (Table 5). This PC can be called "goat production". Higher scores on this factor correspond to small herds of dairy goats with high requirements of labor and scarce presence of cattle.

The second PC attributes for $21.3 \%$ of the variance and explains the SR and its relation to calf sales, annual consumption of supplementary feed and surface ownership (Table 5). This PC can be called "cattle production". The farms that show the higher scores for this factor have calf production, high SR and, consequently, a high consumption of supplementary feed. Besides, these farms have facilities adapted to this livestock management built into the owner's land (not rented).

The third PC accounts for $16.0 \%$ of the original variability and shows the direct relation between percentage of sheep LU, ovine productions (lambs and milk) and annual rents paid (in this case these are the lowest rents) (Table 5). This PC can be called "sheep production". Higher scores on this factor indicate sheep presence and a high percentage of rented grassland.

The fourth PC expresses the relation between technical variables and the economic variability of farms; this explains $11.2 \%$ of the variance (Table 5). This PC can be called "low level of sales". Thus, higher fourth factor scores correspond with low productive farms. 


\subsection{Establishment of the Typology}

The cluster analysis presenting the most significant results is the solution of four clusters or groups (Figure 1). Group 1 (C1) are 7 farms, Group 2 (C2) are 6 farms and Groups 3 (C3) and 4 (C4) consist of 5 farms each.

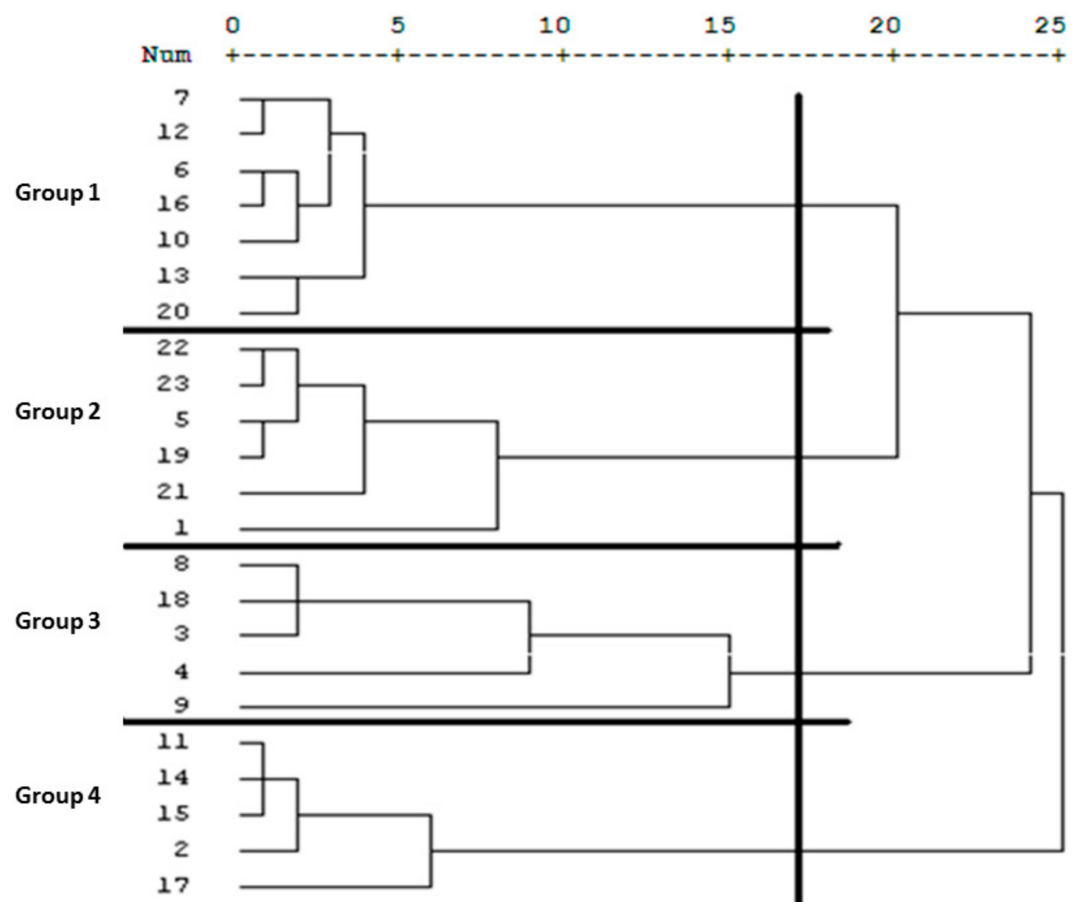

Figure 1. Dendrogram for hierarchical clustering using the Ward's method and the Euclidean distance.

Figure 2 shows the distribution of farms considering the first two components, where scores of farms distinguish the 4 groups formed. $\mathrm{C} 1, \mathrm{C} 2$ and $\mathrm{C} 4$ show greater homogeneity with regard to the first two $\mathrm{PC}$, while $\mathrm{C} 3$ exhibited a greater dispersion of data.

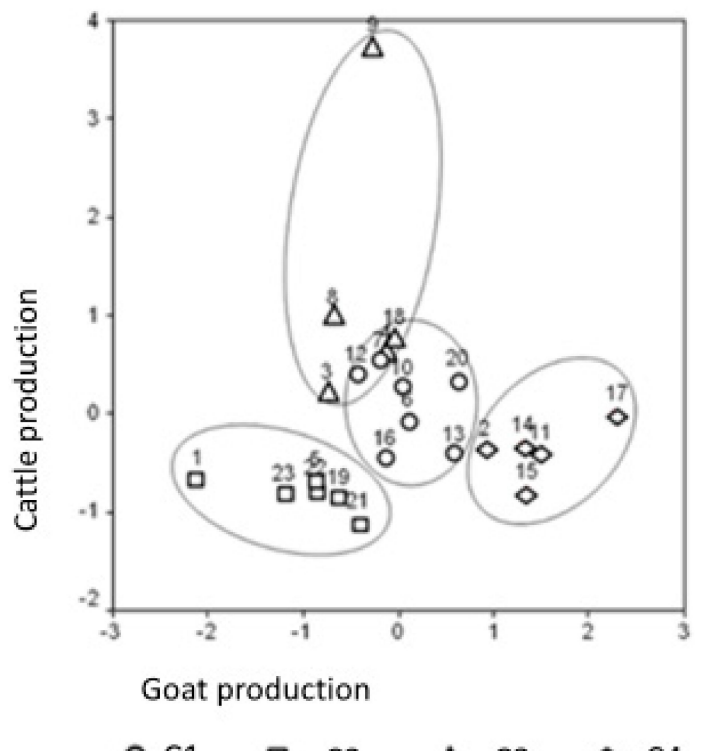

Figure 2. Positioning of the farms according to the scores obtained for principal component 1 (goat production) and principal component 2 (cattle production), where groups C1, C2, C3 and C4 are "medium size farms without sheep", "large size and very extensive farms", "farms with multipurpose sheep" and "farms with dairy goat and without cattle" respectively. 
Table 6 shows the differences between groups or systems and Table 7 shows a schematic comparison of the cluster groups. According to the differences and similarities found between the groups obtained it is possible to describe these as follows.

Table 6. Means of quantitative variables and significance levels from the ANOVA for the characterization of clusters.

\begin{tabular}{|c|c|c|c|c|c|c|c|c|c|c|c|}
\hline \multirow[b]{2}{*}{ Total farm surface (ha) } & \multicolumn{2}{|c|}{$\begin{array}{c}\text { C1 } \\
(n=7)\end{array}$} & \multicolumn{2}{|c|}{$\begin{array}{c}C 2 \\
(n=6)\end{array}$} & \multicolumn{2}{|c|}{$\begin{array}{c}\mathrm{C} 3 \\
(\mathrm{n}=5)\end{array}$} & \multicolumn{2}{|c|}{$\begin{array}{c}C 4 \\
(n=5)\end{array}$} & \multirow{2}{*}{$\begin{array}{c}\begin{array}{c}\text { Total } \\
(\mathbf{n}=23)\end{array} \\
605.16\end{array}$} & \multicolumn{2}{|c|}{$\mathbf{F}$} \\
\hline & 370.93 & $\mathrm{a}$ & 1305.86 & $b$ & 471.43 & $\mathrm{a}$ & 226.00 & a & & 13.03 & $* * *$ \\
\hline $\begin{array}{l}\text { Family work units per area } \\
\text { (WU/100 ha and year) }\end{array}$ & 0.39 & $a b$ & 0.15 & a & 0.63 & bc & 0.69 & c & 0.44 & 11.81 & $* * *$ \\
\hline $\begin{array}{l}\text { Total work units per animal } \\
\text { (WU/100 LU and year) }\end{array}$ & 2.42 & a & 1.60 & a & 1.69 & a & 4.05 & b & 2.40 & 16.29 & $* * *$ \\
\hline Total stocking rate (LU/ha) & 0.18 & a & 0.10 & a & 0.39 & $\mathrm{~b}$ & 0.21 & a & 0.21 & 15.57 & $* * *$ \\
\hline Cattle LU/Total LU (\%) & 48.42 & a & 48.90 & $\mathrm{a}$ & 47.82 & $\mathrm{a}$ & 0.00 & $\mathrm{~b}$ & 37.89 & 13.75 & $* * *$ \\
\hline Sheep LU/Total LU (\%) & 2.44 & a & 34.97 & $\mathrm{~b}$ & 33.74 & $\mathrm{~b}$ & 30.21 & $a b$ & 23.77 & 5.53 & $* *$ \\
\hline Goat LU/Total LU (\%) & 48.82 & a & 15.90 & $\mathrm{~b}$ & 12.64 & $\mathrm{~b}$ & 69.79 & $\mathrm{a}$ & 36.93 & 20.46 & $* * *$ \\
\hline Lambs sold (€/ha and year) & 1.53 & a & 5.50 & a & 22.40 & $\mathrm{~b}$ & 10.50 & $\mathrm{a}$ & 9.05 & 9.31 & $* * *$ \\
\hline Sheep milk sold ( $€$ /ha and year) & 0.00 & $\mathrm{a}$ & 4.83 & $a b$ & 52.41 & $\mathrm{~b}$ & 7.07 & $a b$ & 14.19 & 3.63 & * \\
\hline Calves sold (€/ha and year) & 22.06 & $\mathrm{ab}$ & 7.09 & $\mathrm{a}$ & 56.35 & $\mathrm{~b}$ & 0.00 & $\mathrm{a}$ & 20.81 & 7.55 & ** \\
\hline Kids sold per area (€/ha and year) & 20.97 & $a b$ & 3.15 & $\mathrm{a}$ & 11.91 & $\mathrm{a}$ & 31.81 & $\mathrm{~b}$ & 16.71 & 6.32 & ** \\
\hline Goat milk sold (€/ha and year) & 77.06 & $\mathrm{ab}$ & 11.95 & a & 61.09 & $\mathrm{ab}$ & 146.74 & $\mathrm{~b}$ & 71.75 & 5.79 & ** \\
\hline Profit $(€ /$ ha and year $)$ & 72.74 & $a b$ & 22.37 & a & 184.62 & $\mathrm{~b}$ & 113.71 & $\mathrm{ab}$ & 92.83 & 5.18 & ** \\
\hline
\end{tabular}

Groups: $\mathrm{C} 1=$ medium size farms without sheep, $\mathrm{C} 2=$ large size and very extensive farms, $\mathrm{C} 3=$ farms with multipurpose sheep, $\mathrm{C} 4=$ farms with dairy goat and without cattle. $\mathrm{a}$ and $\mathrm{b}$ : means with different letters show significant differences between groups; ${ }^{*} p<0.05,{ }^{* *} p<0.01,{ }^{* * *} p<0.001$.

Table 7. Schematic comparison of the cluster groups.

\begin{tabular}{|c|c|c|c|c|}
\hline & $\begin{array}{c}\text { C1 } \\
(30.43 \%)\end{array}$ & $\begin{array}{c}C 2 \\
(26.09 \%)\end{array}$ & $\begin{array}{c}\text { C3 } \\
(21.74 \%)\end{array}$ & $\begin{array}{c}C 4 \\
(21.74 \%)\end{array}$ \\
\hline Total farm surface (ha) & Intermediate (300-700) & Large $(>700)$ & (a) & Small $(<300)$ \\
\hline $\begin{array}{l}\text { Family work units per area } \\
\text { (WU/100 ha and year) }\end{array}$ & Intermediate $(0.24-0.50)$ & Low $(<0.24)$ & (a) & High $(>0.50)$ \\
\hline $\begin{array}{l}\text { Total work units per animal } \\
\text { (WU/100 LU and year) }\end{array}$ & Intermediate (2-3) & (a) & Low $(<2)$ & $\operatorname{High}(>3)$ \\
\hline Stocking rate (LU/ha) & Intermediate $(0.14-0.25)$ & Low $(<0.14)$ & High $(>0.25)$ & Intermediate $(0.14-0.25)$ \\
\hline Cattle LU/Total LU (\%) & (a) & (a) & (a) & Non existent \\
\hline Sheep LU/Total LU (\%) & Non existent & (a) & (a) & (a) \\
\hline Goat LU/Total LU (\%) & Intermediate (28-52) & Low $(<28)$ & Low $(<28)$ & High $(>52)$ \\
\hline Lambs sold (€/ha and year) & Non existent & Low $(<10)$ & High $(>18)$ & (a) \\
\hline Sheep milk sold ( $€ /$ ha and year) & Non existent & (a) & High $(>14)$ & Non existent \\
\hline Calves sold ( $€ /$ ha and year) & (a) & Low (3-11) & High $(>23)$ & Non existent \\
\hline Kids sold per area (€/ha and year) & (a) & Low $(<7)$ & (a) & (a) \\
\hline Goat milk sold (€/ha and year) & (a) & Low $(<24)$ & (a) & High $(>90)$ \\
\hline Profit $(€ /$ ha and year $)$ & Intermediate (35-125) & Low $(<35)$ & High $(>125)$ & Variable \\
\hline
\end{tabular}

(a): Variable without influence in group characterization. Groups: $\mathrm{C} 1=$ medium size farms without sheep, $\mathrm{C} 2=$ large size and very extensive farms, C3 = farms with multipurpose sheep, $\mathrm{C} 4=$ farms with dairy goat and without cattle.

\subsubsection{Group 1: Medium Size Farms Without Sheep}

This group represents $30.4 \%$ of farms. These have intermediate values for: farm surface (300-700 ha); labor: per surface ( $0.24-0.50$ family WU/100 ha) and per livestock ( $2-3$ total WU/100 LU); SR (0.14-0.25 LU/ha); and gross margin (35-125€/ha and year) (Tables 6 and 7).

These farms have no sheep, with the exception of a farm with a low percentage of meat sheep (17.1\% of its LU).

\subsubsection{Group 2: Large Size and Very Extensive Farms}

The second group represents $26.1 \%$ of farms. These are the largest farms (surface $>700$ ha). However, these show the lowest values for: labor per surface $(<0.24$ family WU/100 ha); SR $(<0.14 \mathrm{LU} / \mathrm{ha})$; goat presence $(15.9 \%$ of total LU); and have productions with scarce net margin per surface unit $(<35 € /$ ha) (Tables 6 and 7$)$. 


\subsubsection{Group 3: Farms with Multipurpose Sheep}

This group represents $21.7 \%$ of farms. These farms show low values for labor per livestock $(<2 \mathrm{WU} / 100 \mathrm{LU})$ and for goat presence $(<12.64 \%$ of total LU). However, these have a high SR $(>0.25 \mathrm{LU} / \mathrm{ha})$ and a high incomes from calf sales $(>23 € / \mathrm{ha})$, lambs $(>18 € / \mathrm{ha})$ and sheep milk $(>14 € / \mathrm{ha})$; which provide a high annual net margin $(>125 € /$ ha) (Tables 6 and 7$)$.

\subsubsection{Group 4: Farms with Dairy Goat and Without Cattle}

The fourth group represents $21.7 \%$ of farms. These are the smallest ones ( $<300 \mathrm{ha})$, and have the highest values of labor: per surface ( $>0.5$ family WU/100 ha) and per livestock ( $>3$ of total WU/100 LU), as a consequence of milking activities. They show the highest dairy goat presence $(>52 \%$ of total $\mathrm{LU}$ ) and the highest incomes from goat milk sales ( $>90 € / \mathrm{ha}$ ). Their SR is intermediate (from 0.14 to $0.25 \mathrm{LU} / \mathrm{ha}$ ) and do not produce cattle or sheep milk (Tables 6 and 7). The profits of these farms vary greatly, from very high values (up to $300 € /$ ha) to negative values.

\subsection{Comparison of Farm Groups}

The distribution of the farms studied among the four groups obtained is similar, ranging between 21 and $31 \%$ of the total (Table 7). The main differences are the dimension of the surface, the present livestock species, the main production and the level of intensification. Other authors, also studying extensive and semi-extensive livestock systems in Spain, found similar results. Thus, Gaspar et al. [33], for sheep in Extremadura, indicate those differences among the six groups found, but add one more: profitability. Castel et al. [25], for the Andalusian semi-extensive dairy goats, showed the same results for the first three differences between the five groups found, but also add differences for location and percent of rented grassland surface. Milán et al. [26], for Spanish dehesa pastures with cattle, show the first two differences between the three groups obtained and added one more: herd size. But these results do not agree with those found by Perea et al. [52] when a sample of 69 Spanish organic farms around the country were studied and no group in NPSG coincided with their typology.

In Spanish organic farms, other authors like López-i-Gelats and Bartolomé [53] and Toro-Mujica et al. [22] only agree with these results when the groups differ in the level of intensification.

Comparing the most significant characteristics of each of the groups found between the farms that use communal pastures of NPSG, it has been found that the highest average surface (1306 ha) corresponds to the "large size and very extensive farms" (C2); while the other groups have a much lower average surface (between 226 and 471 ha) $(p<0.001)$. These surfaces are slightly higher than those found by Milán et al. [26] for Spanish cattle pastures (257,357 and 1021 ha respectively for each of the three groups set), and those found by Gaspar et al. [33] in Extremadura (with average areas between 156 and 849 ha), and much higher than those indicated by Castel et al. [25] (with average surfaces between 32 and 362 ha).

As far as labor is concerned, C4 ("farms with dairy goat and without cattle") stands out for the highest average $(4.0 \mathrm{WU} / 100 \mathrm{LU})(p<0.001)$; since, as has been said, producing milk is very demanding and requires a higher level of labor in quantity and qualification. These results are far superior to those of other Mediterranean extensive systems in which there is milking, with mean values for farm groups between 1.1 and 2.4 WU/100 LU [26,33].

Regarding SR, the highest one corresponds to C3 ("farms with multipurpose sheep") with a mean value of $0.39 \mathrm{LU} / \mathrm{ha}(p<0.001)$. This average is lower than the maximum group averages of 0.45 , 0.62 and 0.63 LU/ha identified by Milán et al. [26], Castel et al. [25] and Gaspar et al. [33] respectively for extensive and semi-extensive farms in Southern Spain.

The four groups show significant differences in the presence of different species of livestock. Groups C2 and C3 have a similar distribution: nearly half of SR for cattle (49 and 48\% respectively), followed by sheep and a few goats. C4, "farms with dairy goat and without cattle", is the most unbalanced in this regard, showing very high values for goats (70\%) and non-existent cattle. In turn, 
C1 "medium size farms without sheep" shows around 50\% of SR for cattle and goats census. These data differ from those found in other extensive systems in the Spanish Southwest, where there are no goats (i.e., [33,46]).

From the economic point of view the most important factor in all groups is the production of goat's milk, with very different levels in both net values $(€ /$ ha) and percentage values. Goat production is more important in groups $\mathrm{C} 1$ and C4. Sheep production is more important in groups $\mathrm{C} 2$ and C3, although these farms market five products (beef, sheep and goat meat, and sheep and goat milk). C3 is where the average income per hectare is higher, since its production system is the most intensive. The farms belonging to $\mathrm{C} 4$ are clearly unbalanced in favor of the sale of goat's milk, with the highest average income from this source $(147 € / \mathrm{ha})$, which is $75 \%$ of total revenues; resulting in the sale of kids being the second production in economic importance ( $32 € / \mathrm{ha}$ ). $\mathrm{C} 1$ shows intermediate incomes from goat milk sales ( $77 € /$ ha) and calves and kid sales ( $22 € /$ ha and $21 € /$ ha).

Overall, the total incomes from sales amount to (in order of highest to lowest): $203 € /$ ha in C3, $197 € /$ ha in C4, $122 € /$ ha in C1 and $33 € /$ ha in C2. These figures are lower than those of other more intensified organic farming, as those described for dairy sheep in Castilla-La Mancha (Central Spain) by Toro-Mujica et al. [22] with an average between 83 and $368 € /$ ha; and to those found by Gaspar et al. [33] in the six groups of sheep farms found in dehesa farms with averages between 222 and $689 € /$ ha, where there are only revenues from livestock sales (lambs, wool and culling ewes).

Regarding the average profit per ha, farms of C3, which support the highest SR, have the highest average values $(185 € /$ ha); while farms of $C 2$, which have the lowest SR have the lowest ones $(22 € /$ ha) $(p<0.01)$.

With regard to the European Common Policy subsidies for organic production, it is noteworthy that although $73.94 \%$ of farms are registered as organic, for various reasons, only $52.3 \%$ receive this economic support (Table 8); hence, only $39.1 \%$ of NPSG farms receive these subsidies. The groups with the most organic farms are C2 ("large size and very extensive farms") and C3 ("farms with multipurpose sheep"), with $100 \%$ and $80 \%$ of farms registered as organic, respectively. But whereas in C2 only $33 \%$ of the organic farms receive the subsidy, in C3 it is received by $75 \%$ (Table 8 ). Of the other two groups organic farms receiving subsidies are $50 \%$ of $\mathrm{C} 1$ ("medium size farms without sheep") and $66.7 \%$ of C4 ("farms with dairy goat and without cattle"); so it is in C2 where there is the smallest percentage of organic farms receiving this support, and C3 is where this percentage is the highest (Table 8). This aspect leads to $\mathrm{C} 3$ being the farm with the greatest profits.

Table 8. Distribution of cluster groups for variables related to organic farming.

\begin{tabular}{cccccc}
\hline & C1 & C2 & C3 & C4 & Total \\
\hline Organic farms (\%) & 57.1 & 100.0 & 80.0 & 60.0 & 73.9 \\
Organic farms receiving subsidies to organic farming (\%) & 50.0 & 33.3 & 75.0 & 66.7 & 52.9 \\
Farms receiving subsidies to organic farming in NPSG (\%) & 28.6 & 33.3 & 60.0 & 40.0 & 39.1 \\
\hline
\end{tabular}

Groups: $\mathrm{C} 1$ = medium size farms without sheep, $\mathrm{C} 2$ = large size and very extensive farms, $\mathrm{C} 3$ = farms with multipurpose sheep, $\mathrm{C} 4=$ farms with dairy goat and without cattle.

\section{Discussion}

The pastures used by the farms studied are mostly leased, being mainly public property (common grasslands), which is an exception in Spanish PNA, where most of the farms are private estates $[3,4,7]$. This fact determines the investments in improving structures. Faced with this situation, it should be taken into consideration that a high proportion of the NPSG farms $(86.9 \%)$ have dairy goats (infrequent when compared to other similar agroecosystems) and that this production system requires some special equipment and facilities for milking, and country roads to be in good condition for daily milk transport. Besides, according to Martín Bellido et al. [43] this herd size would be large and unusual; these authors indicate that goat herds with more than 30 LU have low frequency in Andalusia and Extremadura 
(6.7 and 6.6\%, respectively). By contrast, Gaspar [46] shows much larger herds of sheep for dehesa farms (150.2 LU vs. 40.0 LU in NPSG); however, those herds studied by Gaspar were not dairy.

As has been found, from an economic point of view, the most important production in all groups is goat's milk, mainly in groups $\mathrm{C} 1$ and $\mathrm{C} 4$ ( $\mathrm{C} 4$ standing out where milk is $75 \%$ of total revenue). Both groups have an intermediate SR (0.14-0.25 LU/ha) when compared to the farms studied. But the mean SR of the farms that use communal pastures of the NPSG $(0.21 \mathrm{LU} / \mathrm{ha})$ is higher than the average of $0.13 \mathrm{LU} /$ ha shown by Rodríguez-Estévez et al. [4] for all the organic farms in the NPSG $(n=67)$. This could be evidence for the current tendency of dairy farms to rapid intensification [54]. In general, extensive dairy goat farms are more dependent on feed for a better milk yield, therefore they should either reduce their workforce costs or better sell their products [28], whether directly transformed, organically certified or both.

However, the mean SR of the farms that use communal pastures of the NPSG $(0.21 \mathrm{LU} / \mathrm{ha})$ is much lower than the SR of $0.36 \mathrm{LU} /$ ha found by Mena et al. [55] for dairy goat farms in the same mountain area of the NPSG; and is much lower than the SR of $0.43 \mathrm{LU} /$ ha found by Perea et al. [52] for a sample of 69 Spanish organic farms, comprising around half of the farms. So, as Carpio et al. [56] indicate, the standards for organic livestock farming detailed by the OF regulations of the European Community [12] allow intensive open air production, without grazing and feeding animals with organic compound feeds adding green or conserved fodder. Hence, organic milk production only has to pass the minimum standard of OF feeding, but does not imply grazing because the limit for SR is 1.4 LU/ha. However, communal pastures of the NPSG need well-adjusted SR grazing livestock herds for its conservation and with this aim OF are preferenced in the use of communal pastures of the NPSG, as is indicated in its Use and Management Regulation [27]. This is in agreement with the perception of farmers who believe that agroforestry is the most adequate land use for this NPA, as Lovrić et al. [57] show for farmers from many marginal rural Mediterranean areas.

In relation to average profit per ha, it is evident that, the fact that the most intensified farms, C3 $(0.39 \mathrm{LU} / \mathrm{ha})$, generate the most profit and the least intensified ones produce the least profit; thus profit can promote intensification by farmers as is the general tendency [3], thereby putting at risk NPSG environmental conservation. So, intensification in organic farming can lead to a lack of sustainability, both from an environmental point of view (overgrazing and imbalance) and economically. Thus, Toro-Mujica et al. [22] found that the profits of the organic dairy sheep farms of Castilla-La Mancha were lower $(4 € /$ ha) due to their higher costs of feed (less grazing and more supplementary feeding) and their high investment in infrastructure and equipment. However, in recent years there has been a remarkable decrease in grazing in goat systems, leading to rapid intensification; and in the case of dairy herds there has been a high evolution towards "false grazing systems", whereby the animals graze daily but most of their nutritional requirements are covered by forage and concentrates given in the stable [54]. This scenario would be a problem for the conservation of the NPSG communal pastures and its grazing systems, losing its environmental sustainability. Besides that, intensification would come with the loss of agroforestry benefits from integrating trees in livestock systems; which include, among others, animal welfare, disease control, diversification of feed resources, nutrient retention and increased biodiversity [15].

However it must be recognized that $\mathrm{C} 3$ is where the average income per hectare is the highest $(185 € / \mathrm{ha})$ and, at the same time, is the most interesting from the rural development point of view with C4 (0.63 and 0.69 familiar WU/100 ha, respectively), because the production of milk in semi-extensive systems is more related to small and family farms [25].

This justifies the interest in authentic OF conversion for livestock grazing in communal pastures by the responsible authorities of NPSG. Accordingly, as Díaz-Gaona et al. [3] indicate, all authorities involved throughout all stages of the control, inspection and surveillance of OF livestock production, as a system based on the harmonious relationship between land, plants and livestock, should guarantee a balanced SR. What is more, this necessary equilibrium is the reason why the administration of NPSG gives priority to OF. On the other hand, there is a very clear need to market differentiated products 
from extensive farming so that they get added value to make more profit based on the social demand of environmentally-friendly and high quality products [42]. This loss of differentiation once on the market, or lack of increase in market price has been reported by other authors; i.e., Perea et al. [52] indicate that only $40.6 \%$ of the Spanish farms surveyed commercialize calves certified as organic on the market. Any campaign launched by the NPSG administration or the development of a local quality brand in support of these more sustainable farms would be a good help, along with some specific carbon footprint certification [42]. However, all those opportunities go through marketing; which is one of the pending subjects for all of these farmers. Escribano [58] recommends transversal support measures to train consumers' level of cognizance regarding organic food and their readiness to pay premium prices, making it clear that this is the way to support farmers' conservation of high nature value grasslands.

Group C2 farms, which are forcing less production, are those with the greatest ease of conversion to organic production; but without access to these subsidies and without differentiation in the market, their competitiveness is greatly reduced. There is general agreement between experts that the implementation of specific lines of subsidies encouraging the production of organic livestock in high ecological value ecosystems would be desirable [14]. Therefore, it is essential that, in the meanwhile, $\mathrm{C} 2$ farms and other groups can resolve incidents (most of which are bureaucratic) that are impeding the receiving of current subsidies.

This last fact about bureaucracy and the lack of differentiated marketing should be resolved by local authorities with the aim to support and conserve the traditional farming systems because the NPSG needs these in order to conserve its communal pastures without shrub invasion. The experts highlight that the lack, or stagnation, of sales of the final product as organically certified is a relevant aspect that hinders the implementation of organic livestock in high ecological value ecosystems [14]. The achievement of an extra price for organic products mainly implies the failure or success of the adaptation of these farms to these ecologically-valuable ecosystems. Escribano indicates that organic livestock farms need to adapt to a new global market context [58]. Besides, primary reasons for the difficulty of recruitment and farmer turnover included a lack of candidate farmers in the local landscape, and the marginal and fluctuating economics of grassland management. Behind all this lies the problem of a lack of generational relief, with the consequent disappearance of farmers and the abandonment of pastures. As McGinlay et al. [8] indicate, the main reasons for difficulty of recruitment and farmer turnover include a lack of candidate farmers in the local landscape, and the marginal and fluctuating profits of grassland management.

\section{Conclusions}

The research presented provides a solid basis for knowledge of the current scenario of the farms that use communal pastures in NPSG. These farms have a higher level of extensive production than other extensive livestock systems in Southwestern Spain and other Spanish organic farms; the former with more pasture surfaces, lower stocking density and a higher proportion of autochthonous breeds, in accordance with OF principles.

There are diverse livestock systems using common grasslands in NPSG, with different surfaces and different combinations and proportions of livestock species, leading to various productions with different impacts on productive results and levels of intensification. The level of intensification largely determines the two variance factors that best explain the differences between farms: those relating to "goat products" and "cattle production".

Of the four farming typologies identified, the group called "farms with multipurpose sheep" is that which supports the highest SR and has the highest profit; contrary to what happened with "large size and very extensive farms". These economic differences are increased by the fact that the latter farms are those with the highest percentage of incidents when trying to collect support for OF; while the former are those with the lowest percentage of incidents of this type. However, very extensive 
farms are the most interesting for natural park conservation and, hence, the regional administration should help to resolve those incidents.

The farms studied have a high association with milk production, which contributes to nearly half of incomes, generates a high demand for labor and contributes to rural development. So, the profitability of dairy production should increase for future consolidation by means of differentiated commercialization.

Organic farming offers NPSG a commitment to conserve the natural park ecosystems, and to farmers a profitability equal to or greater than the area average; even when the commercial channels leading to a premium for the sale of these certificated and differentiated quality products are not developed. Therefore, organic farming can be a suitable tool for managing this protected natural area, which needs grazing to maintain vegetation equilibrium. However, NPSG authorities or the highest level of the regional government should help to improve the economic viability and continuity of the largest possible number of farms, which generate rural development (employment) while conserving the NP. This could be supported by the adoption of administrative measures to resolve incidents and to avoid bureaucratic hindrances.

A similar policy could be followed in other European HNV farmlands and pastures located in 'less-favoured' areas from an economic perspective, with a risk of abandonment.

Author Contributions: Conceptualization, C.D.-G. and V.R.-E.; methodology, C.D.-G., T.R.-P., M.S.-R. and V.R.-E.; validation, C.D.-G. and T.R.-P.; formal analysis, C.D.-G. and V.R.-E.; investigation, C.D.-G., T.R.-P. and V.R.-E.; resources, M.S.-R. and V.R.-E.; data curation, C.D.-G. and V.R.-E.; writing - original draft preparation, C.D.-G., M.S.-R. and V.R.-E.; writing-review and editing, C.D.-G. and V.R.-E.; funding acquisition, C.D.-G., M.S.R. and V.R.-E.

Funding: This research was funded by Consejería de Medio Ambiente (Junta de Andalucía, Spain) and Asociación Valor Ecológico CAAE (Ecovalia).

Acknowledgments: The authors are grateful to the Natural Park Sierra de Grazalema authorities for their technical support and to organic farmers for their collaboration and for preserving and enhancing the legacy of the traditional farming systems while conserving and reshaping the future of natural parks every day.

Conflicts of Interest: The authors declare no conflicts of interest. The funders had no role in the design of the study; in the collection, analyses, or interpretation of data; in the writing of the manuscript, or in the decision to publish the results.

\section{References}

1. Schröder, B.R.H.F.R. Pasture Landscapes and Nature Conservation; Springer: Berlin/Heidelberg, Germany, 2002.

2. EUROPARC-España. Anuario 2018 del Estado de las áreas Protegidas en España; Fundación Fernando González Bernáldez: Madrid, Spain, 2019; p. 130.

3. Díaz-Gaona, C.; Sánchez-Rodríguez, M.; Gómez-Castro, G.; Rodríguez-Estévez, V. La ganadería ecológica en la gestión de los espacios naturales protegidos: Andalucía como modelo. Arch. Zootec. 2014, 63, $25-54$. [CrossRef]

4. Rodríguez-Estévez, V.; Díaz-Gaona, C.; Sánchez-Rodríguez, M. La ganadería ecológica como herramienta de conservación de los parques naturales Andaluces. In Informe Anual del Sector Agrario en Andalucía 2009; Analistas Económicos de Andalucía: Málaga, Spain, 2010; pp. 417-429.

5. Consejería de Agricultura, Ganadería, Pesca y Desarrollo Sostenible. Available online: http://www. juntadeandalucia.es/medioambiente/site/portalweb/menuitem.220de8226575045b25f09a105510e1ca/ ?vgnextoid=8ac0ee9b421f4310VgnVCM2000000624e50aRCRD (accessed on 11 June 2019).

6. European Environment Agency. Protected Areas in Europe-An Overview; EEA: Copenhagen, Denmark, 2012; ISBN 9789292133290.

7. EUROPARC-España. Anuario EUROPARC-España del Estado de los Espacios Naturales Protegidos 2005; Fundación Fernando González Bernáldez: Madrid, Spain, 2006; p. 160.

8. McGinlay, J.; Gowing, D.J.G.; Budds, J. The threat of abandonment in socio-ecological landscapes: Farmers' motivations and perspectives on high nature value grassland conservation. Environ. Sci. Policy 2017, 69, 39-49. [CrossRef]

9. European Environment Agency. High Nature Value Farmland: Characteristics, Trends, and Policy Challenges; European Environment Agency: Copenhagen, Denmark, 2004; ISBN 9291676640. 
10. Paracchini, M.L.; Petersen, J.-E.; Hoogeveen, Y.; Bamps, C.; Burfield, I.; Swaay, C. Van High Nature Value Farmland in Europe-An Estimate of the Distribution Patterns on the Basis of Land Cover and Biodiversity Data; OPOCE: Luxembourg, 2008; ISBN 9789279095689.

11. Bernués, A.; Ruiz, R.; Olaizola, A.; Villalba, D.; Casasús, I. Sustainability of pasture-based livestock farming systems in the European Mediterranean context: Synergies and trade-offs. Livest. Sci. 2011, 139, 44-57. [CrossRef]

12. European Union. Council Regulation (EC) No 834/2007 of 28 June 2007 on organic production and labelling of organic products and repealing Regulation (EEC) No 2092/91. Off. J. Eur. Union 2007, L189, 1-23.

13. Oudshoorn, F.W.; Sørensen, C.A.G.; de Boer, I.J.M. Economic and environmental evaluation of three goal-vision based scenarios for organic dairy farming in Denmark. Agric. Syst. 2011, 104, 315-325. [CrossRef]

14. Horrillo, A.; Escribano, M.; Mesias, F.J.; Elghannam, A.; Gaspar, P. Is there a future for organic production in high ecological value ecosystems? Agric. Syst. 2016, 143, 114-125. [CrossRef]

15. Burgess, P.J.; Rosati, A. Advances in European agroforestry: Results from the AGFORWARD project. Agrofor. Syst. 2018, 92, 801-810. [CrossRef]

16. European Union. Council Regulation (EEC) No. 2092/91 of 24 June 1991 on organic production of agricultural products and indications referring thereto on agricultural products and foodstuffs. Off. J. Eur. Union 1991, L198, 1-15.

17. European Union. Commission Regulation (EC) No 889/2008 of 5 September 2008 laying down detailed rules for the implementation of Council Regulation (EC) No 834/2007 on organic production and labelling of organic products with regard to organic production, labeling and control. Off. J. Eur. Union 2008, 250, 1-84.

18. Mądry, W.; Mena Guerrero, Y.; Roszkowska-Madra, B.; Gozdowski, R.; Hryniewski, R.; Castel Genís, J.M. An overview of farming system typology methodologies and its use in the study of pasture-based farming system: A review. Span. J. Agric. Res. 2013, 11, 316-326. [CrossRef]

19. Riveiro, J.A.; Mantecón, A.R.; Álvarez, C.J.; Lavín, P. A typological characterization of dairy Assaf breed sheep farms at NW of Spain based on structural factor. Agric. Syst. 2013, 120, 27-37. [CrossRef]

20. Gaspar, P.; Escribano, A.J.; Mesías, F.J.; Escribano, M.; Pulido, A.F. Goat systems of Villuercas-Ibores area in SW Spain: Problems and perspectives of traditional farming systems. Small Rumin. Res. 2011, 97, 1-11. [CrossRef]

21. Gibon, A.; Sibbald, A.R.; Flamant, J.C.; Lhoste, P.; Revilla, R.; Rubino, R.; Sørensen, J.T. Livestock farming systems research in Europe and its potential contribution for managing towards sustainability in livestock farming. Livest. Prod. Sci. 1999, 61, 121-137. [CrossRef]

22. Toro-Mujica, P.; García, A.; Gómez-Castro, A.; Perea, J.; Rodríguez-Estévez, V.; Angón, E.; Barba, C. Organic dairy sheep farms in south-central Spain: Typologies according to livestock management and economic variables. Small Rumin. Res. 2012, 104, 28-36. [CrossRef]

23. Milán, M.J.; Arnalte, E.; Caja, G. Economic profitability and typology of Ripollesa breed sheep farms in Spain. Small Rumin. Res. 2003, 49, 97-105. [CrossRef]

24. Milán, M.J.; Caja, G.; González-González, R.; Fernández-Pérez, A.M.; Such, X. Structure and performance of Awassi and Assaf dairy sheep farms in northwestern Spain. J. Dairy Sci. 2011, 94, 771-784. [CrossRef]

25. Castel, J.M.; Mena, Y.; Delgado-Pertıñez, M.; Camúñez, J.; Basulto, J.; Caravaca, F.; Guzmán-Guerrero, J.L.; Alcalde, M.J. Characterization of semi-extensive goat production systems in southern Spain. Small Rumin. Res. 2003, 47, 133-143. [CrossRef]

26. Milán, M.J.; Bartolomé, J.; Quintanilla, R.; García-Cachán, M.D.; Espejo, M.; Herráiz, P.L.; Sánchez-Recio, J.M.; Piedrafita, J. Structural characterisation and typology of beef cattle farms of Spanish wooded rangelands (dehesas). Livest. Sci. 2006, 99, 197-209. [CrossRef]

27. Ambiente, C.D.M. Decreto 90/2006, de 18 de Abril, por el que se Aprueban el Plan de Ordenación de los Recursos Naturales y el Plan Rector de Uso y Gestión del Parque Natural Sierra de Grazalema; Junta de Andalucía: Sevilla, Spain, 2006.

28. Mena, Y.; Ruiz-Mirazo, J.; Ruiz, F.A.; Castel, J.M. Characterization and typification of small ruminant farms providing fuelbreak grazing services for wildfire prevention in Andalusia (Spain). Sci. Total Environ. 2016, 544, 211-219. [CrossRef]

29. Mata Moreno, C.; Maurer, P.; Rodríguez Estévez, V.; Fernández, R.A. Recopilación del Conocimiento Ganadero Tradicional de la Comarca de la Sierra de Cádiz y su Validación Para la Reconversión e Implantación de la Ganadería Ecológica; ASAJA-UCO Producción Animal: Córdoba, Spain, 2004. 
30. De León, A. Caracterización Agroclimática de la provincia de Cádiz; Ministerio de Agricultura, Pesca y Alimentación: Madrid, Spain, 1989; p. 175.

31. Fernández-Cancio, A.; NavarroCerrillo, R.M.; Fernández, R.F.; Hernández, P.G.; Meneéndez, E.M.; Martínez, C.C. Climate classification of Abies pinsapo Boiss. Forests in Southern Spain. For. Syst. 2007, 16, 222-229. [CrossRef]

32. Dobremez, L.; Bousset, J.-P. Rendre Compte de la Diversité des Explotations Agricoles: Une Démarche D'analyse par Exploration Conjointe de Sources Statistiques, Comptables et Technico-Économiques; Centre National du Machinisme Agricole du Génie Rural des Eaux et des Forêts: Paris, France, 1996; ISBN 2853624501.

33. Gaspar, P.; Escribano, M.; Mesías, F.J.; de Ledesma, A.R.; Pulido, F. Sheep farms in the Spanish rangelands (dehesas): Typologies according to livestock management and economic indicators. Small Rumin. Res. 2008, 74, 52-63. [CrossRef]

34. Uriel, E.; Aldas, J. Análisis Multivariante Aplicado; Thompson: Madrid, Spain, 2005; Volume 76.

35. Hair, J.F.; Anderson, R.E.; Tatham, R.L.; Black, W.C. Análisis Multivariante; Prentice Hall: Madrid, Spain, 1999; Volume 491.

36. Malhotra, N.K. Investigación de Mercados: Un Enfoque Aplicado. Pearson Educación: Naucalpan de Juárez, México, 2004; ISBN 9702604915.

37. Martínez-González, M.Á.; Sánchez-Villegas, A.; Faulín, F.J. Bioestadística Amigable; Díaz de Santos: Barcelona, Spain, 2008; ISBN 8490225001.

38. Rodríguez-Estévez, V.; Sánchez-Rodríguez, M.; Arce, C.; García, A.R.; Perea, J.M.; Gómez-Castro, A.G. Consumption of Acorns by Finishing Iberian Pigs and Their Function in the Conservation of the Dehesa Agroecosystem. In Agroforestry for Biodiversity and Ecosystem Services—Science and Practice; InTech: Rijeka, Croatia, 2012; pp. 1-22.

39. Escribano, M.; de Ledesma, A.R.; Mesías, F.J.; Pulido, F. Niveles de cargas ganaderas en la dehesa extremeña. Arch. Zootec. 2002, 51, 315-326.

40. Ministerio de Agricultura, Pesca y Alimentación. Tierras Resultados Técnico-Económicos del Vacuno de Carne 2008; Castilla y León y Navarra: Andalucía, Spain, 2010; Volume 165, pp. 43-50.

41. Perea, J.M.; García, A.; Valerio, D.; Acero, R.; Romero, M.; Alcántara, A. Buenas Prácticas en Producción Ecológica; Producción de Bovino de Carne (Ciclo completo); Ministerio de Medio Ambiente y Medio Rural y Marino: Madrid, Spain, 2008.

42. Gutierrez-Peña, R.; Mena, Y.; Ruiz, F.A.; Delgado-Pertíñez, M. Strengths and weaknesses of traditional feeding management of dairy goat farms in mountain areas. Agroecol. Sustain. Food Syst. 2016, 40, 736-756. [CrossRef]

43. Bellido, M.; Sánchez, M.E.; Díaz, F.J.M.; de Ledesma, A.R.; García, F.P. Sistemas extensivos de producción animal. Arch. Zootec. 2001, 50, 465-489.

44. Sánchez, M.; Santos Alcudia, R.; Gil Rubio, M.J. Evolución y resultados de la producción de leche del grupo caprino de COVAP. In Proceedings of the XXVIII Jornadas Científicas y VII Internacionalesde la Sociedad Española Ovinotecnia y Caprinotenia, Badajoz, Spain, 25-27 September 2003; pp. 124-127.

45. Perea, J.; García, A.; Acero, R.; Valerio, D.; Rodríguez, V. Caracterización productiva del vacuno ecológico en Andalucía. Arch. Zootec. 2007, 56, 517-521.

46. García, P.G. Evaluación Técnico-Económica y Caracterización de Sistemas Ganaderos Extensivos en Dehesas de Extremadura; Universidad de Extremadura: Badajoz, Spain, 2007.

47. Ruiz, F.A.; Castel, J.M.; Mena, Y.; Camúñez, J.; González-Redondo, P. Application of the technico-economic analysis for characterizing, making diagnoses and improving pastoral dairy goat systems in Andalusia (Spain). Small Rumin. Res. 2008, 77, 208-220. [CrossRef]

48. García, A.; Domenech, V.; Frías, J.J.; Herrera, M.; Peña, F.; Martos, J.; Acero, R. Caracterización Técnico-Económica de los Sistemas de Producción de Caprino Extensivo en la Provincia de Jaén Como Base del Desarrollo Sostenible; Analista Económicos de Andalucióa: Málaga, España, 1999; ISBN 849519113X.

49. Mateos, E. EI ganado caprino en el nordeste cacereño. Mundo Ganad. 1990, 9, 29-35.

50. García, A.; Perea, J.; Acero, R. Estrategias comerciales de los sectores ganaderos ecológicos. Incidencia de las subvenciones. In Informe Anual del Sector Agrario en Andalucía 2008; Analistas Económicos de Andalucía: Málaga, España, 2009; pp. 293-316. 
51. European Union. Council Regulation (EC) No 1698/2005 of 20 September 2005 on support for rural development by the European Agricultural Fund for Rural Development (EAFRD). Off. J. Eur. Union 2005, L277, 1-40.

52. Perea, J.; Penedo, I.B.; Barba, C.; Angón, E.; García, A. Organic beef farming in Spain: Typology according to livestock management and economic variables. Rev. Cient. 2014, 24, 347-354.

53. López-i-Gelats, F.; Bartolomé, J. Typologies of organic beef farms in Catalonia. Options Méditerranéennes. Série A Séminaires Méditerranéens 2010, 92, 45-48.

54. Castel, J.M.; Mena, Y.; Ruiz, F.A.; Camúñez-Ruiz, J.; Sánchez-Rodríguez, M. Changes occurring in dairy goat production systems in less favoured areas of Spain. Small Rumin. Res. 2011, 96, 83-92. [CrossRef]

55. Mena, Y.; Gutierrez-Peña, R.; Ruiz, F.A.; Delgado-Pertíñez, M. Can dairy goat farms in mountain areas reach a satisfactory level of profitability without intensification? A case study in Andalusia (Spain). Agroecol. Sustain. Food Syst. 2017, 41, 614-634. [CrossRef]

56. Carpio, A.; Bonilla-Valverde, D.; Arce, C.; Rodríguez-Estévez, V.; Sánchez-Rodríguez, M.; Arce, L.; Valcárcel, M. Evaluation of hippuric acid content in goat milk as a marker of feeding regimen. J. Dairy Sci. 2013, 96, 5426-5434. [CrossRef] [PubMed]

57. Lovrić, M.; Rois-Díaz, M.; den Herder, M.; Pisanelli, A.; Lovrić, N.; Burgess, P.J. Driving forces for agroforestry uptake in Mediterranean Europe: Application of the analytic network process. Agrofor. Syst. 2018, 92, 863-876. [CrossRef]

58. Escribano, A. Beef Cattle Farms' Conversion to the Organic System. Recommendations for Success in the Face of Future Changes in a Global Context. Sustainability 2016, 8, 572. [CrossRef]

(C) 2019 by the authors. Licensee MDPI, Basel, Switzerland. This article is an open access article distributed under the terms and conditions of the Creative Commons Attribution (CC BY) license (http://creativecommons.org/licenses/by/4.0/). 